\title{
Morphometric Analysis for Evaluation of Environmental Change and Disaster Reduction of Flood
}

\author{
I. Akbar $^{1,}$ B. Setiawan ${ }^{2}$ \\ ${ }^{1}$ Geological Engineering, Sriwijaya University, Palembang, Indonesia \\ ${ }^{2}$ Geological Engineering Lecturer, Sriwijaya University, Palembang, Indonesia \\ Corresponding Author: ichsanulakhbar@gmail.com

\begin{tabular}{llll} 
Article history & & \\
\hline Received & Received in revised form & Accepted & Available online \\
03 May 2019 & 27 June 2019 & 30 August 2019 & 31 August 2019 \\
\hline
\end{tabular}

\begin{abstract}
One indicator of environmental change due to climate change and human activities is the change in river flow and its dynamics seen on the visible scale of river flow. This study uses geomorphic data, these data are important factors for understanding natural processes that occur, efforts to reduce and flood risk management. This change in river morphometry will affect the characteristics of the river flow, especially in areas that have meanders. This study was carried out by analyzing the Ogan River flow located in the Ulak Pandan area and its surroundings by comparing changes in river flow in 1990 and 2016 and land use at the study site. The morphometric changes were analyzed by parameters such as changes in the width of the river and sinuosity to evaluate the type of change that occurred. The results of the analysis showed that the increase in river width and the sinuosity index value on the scale showed that river meanders 5, 6 and 7 represented changes with the highest increase, whereas for land use changes there was an increase in plantation land and agricultural land. This, indirectly, changes in land use change, destruction of the natural vegetation of the river system which results in degradation of river flow, especially in the outer meander arc.
\end{abstract}

Keywords: morphometric parameters, meanders, land cover.

\begin{abstract}
Abstrak (Indonesian): Salah satu indikator perubahan lingkungan akibat perubahan iklim dan aktivitas manusia adalah perubahan alur sungai dan dinamikanya yang terlihat pada skala tampak aliran sungai. Studi ini menggunakan data geomorfik, data tersebut merupakan faktor penting untuk memahami proses alam yang terjadi, upaya pengurangan dan manajemen risiko banjir. Perubahan morfometri sungai ini akan mempengaruhi karakteristik aliran sungai, terutama pada daerah yang memiliki meander. Studi ini dilakukan Analisa pada aliran Sungai Ogan yang terletak di daerah Ulak Pandan dan sekitarnya dengan membandingkan perubahan aliran sungai pada tahun 1990 dan 2016 serta penggunaan lahan pada lokasi penelitian. Perubahan morfometri tersebut dianalisa dengan parameter berupa perubahan lebar sungai dan sinousitas untuk evaluasi tipe perubahan yang terjadi. Hasil dari Analisa tersebut menunjukkan bahwa terjadinya peningkatan lebar sungai serta nilai indeks sinuositas pada skala tampak meander sungai 5, 6 dan 7 yang mewakili perubahan dengan peningkatan tertinggi, sedangkan untuk perubahan penggunaan lahan terjadi peningkatan pada lahan perkebunan dan lahan pertanian. Hal ini, secara tidak langsung mengalami perubahan alih fungsi lahan, penghancuran terhadap vegetasi alami sistem sungai yang mengakibatkan degradasi aliran sungai, terutama pada busur luar meander.
\end{abstract}

Katakunci: parameter morfometri, meander, penggunaan lahan.

\section{Introduction}

Indonesia was an archipelago with abundant water availability. The water was a vital need for the lives of humans and other living things. Ulak Pandan Village and its surroundings were located in the city of Baturaja located along the watershed. Watershed was a water catchment area on a land area, topographically limited by hills and mountains that could accommodate and store rainwater then flow to the main river. The shape of a winding river called meander, influenced by various factors consisting of a series of loops occurring along the watershed in a fluvial system, with irregular shapes and sizes [1].

Meander is a form of river that twists and turns. The meander formation process is produced by changes in river currents looking for weak zones so that erosion and precipitation occur on the banks of the river which makes the river bend even greater. The winding river would always move because of the process of erosion and sedimentation in a sustainable fluvial river system. Changes in river morphometry affect river flow characteristics, especially in winding watersheds. These changes were closely related to land cover around the watershed. Human activities have an essential role in changing land cover, which can affect river morphology and dynamics. Land cover is one of the factors that can cause changes in river flow, several other factors such as geology, rainfall and climate. Changes in land cover are influenced by several human activities such as land clearing of shrubs into plantation land, which results in morphological changes in the width of the river. These changes increase certain land 


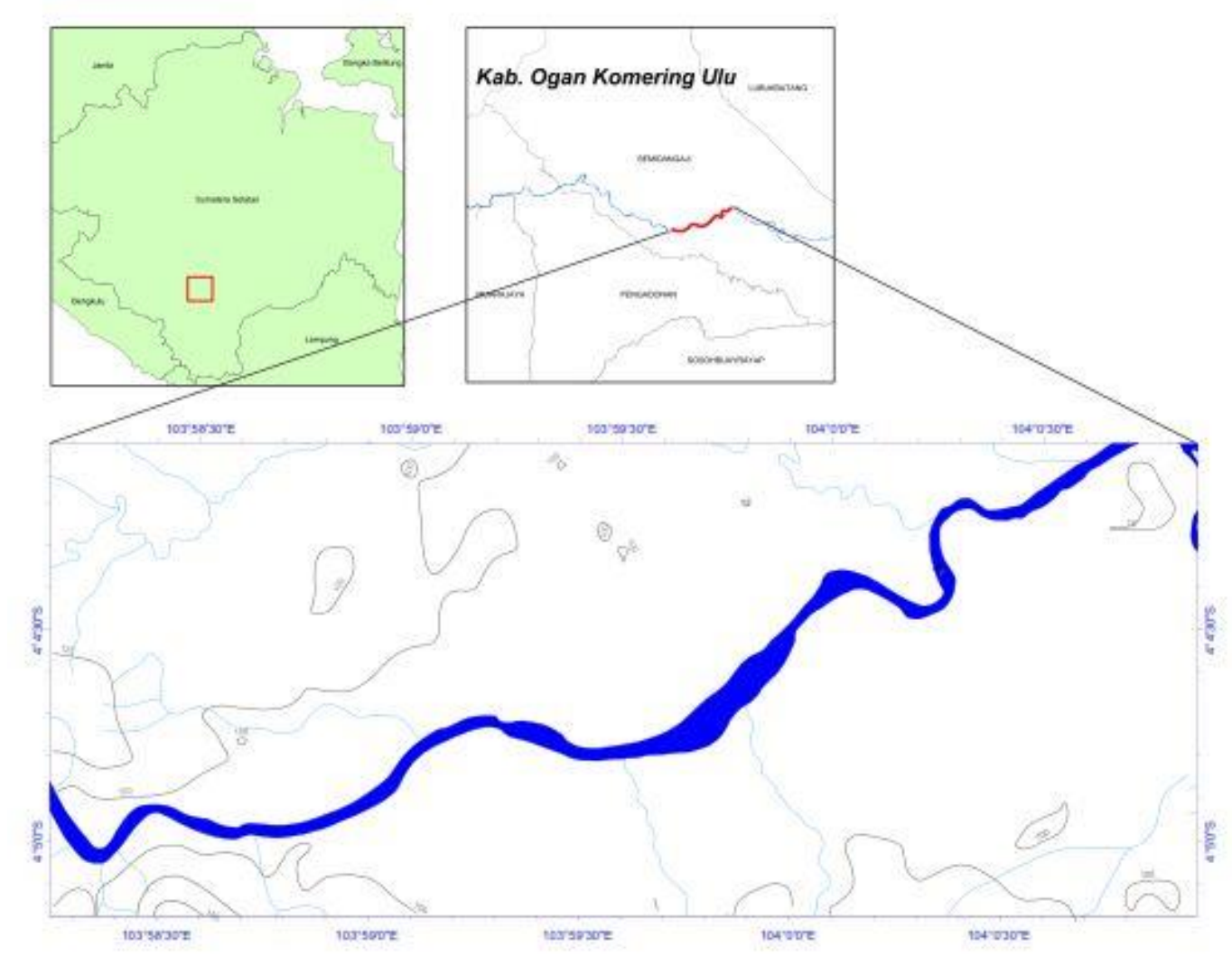

Figure 1. Location of the study area

This research was carried out on a river body that has a meander by comparing changes in river morphometry parameters in 1990 and 2016. Composition lithology at the research site is dominated by sedimentary rocks in the form of alluvial deposits, where the rock is less resistant so that it affects erosion on the banks of the river, especially on the banks of the river.

\section{Research Methods}

The supervised classification of maximum likelihood is one of the most commonly used in determining the type of land cover. Training area that had been determined for each type of land cover, such as plantations and rice fields, residential land and vacant land, and water area (rivers) by conducting direct surveys in the field using GPS (global positioning system). Maximum likelihood is an algorithm that is related to pixel values to get the maximum similarity of a vector that has not been classified based on the class that has been specified in the training sample for each land cover object [3]. The following is a research method flowchart (Figure 2). 


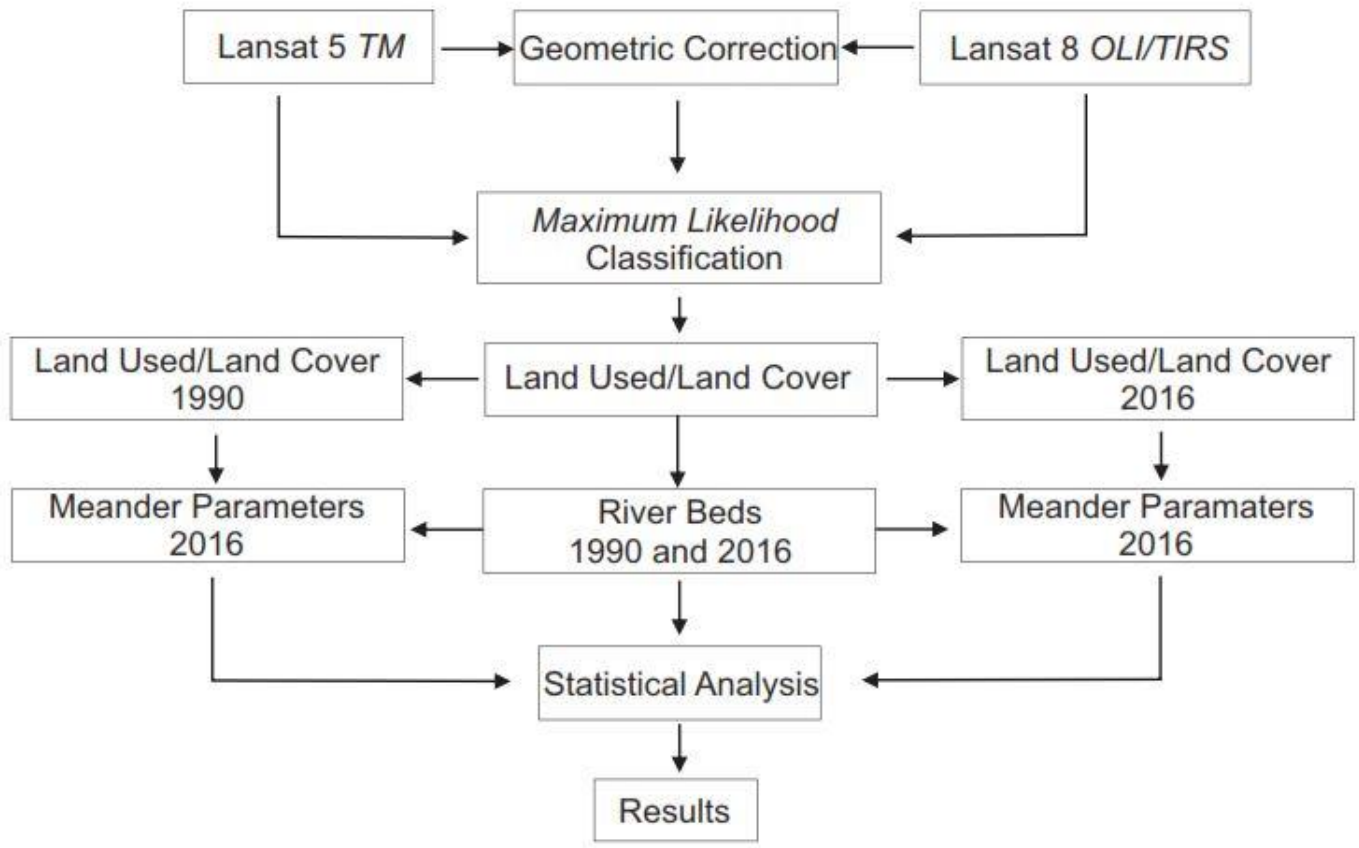

Figure 2. Chart of research flow

The river parameter meander used: river width (W), water flow length (S), meander neck length (L), axis length (A), radius of curvature (R) and sinuosity (C) calculated by equation $(\mathrm{C}=\mathrm{S} / \mathrm{L})$ based on the meander parameter curve model [4]. Based on the parameters, the width of the river is the lowest average distance of the river bank, the length of the water flow is the length between two winding aspects, for the neck length is the lowest distance of two winding loops, on the river axis length that is the distance between the internal bow meander and the neck which is winding next the curvature radius which is the maximum interior radius in the circle that circles.

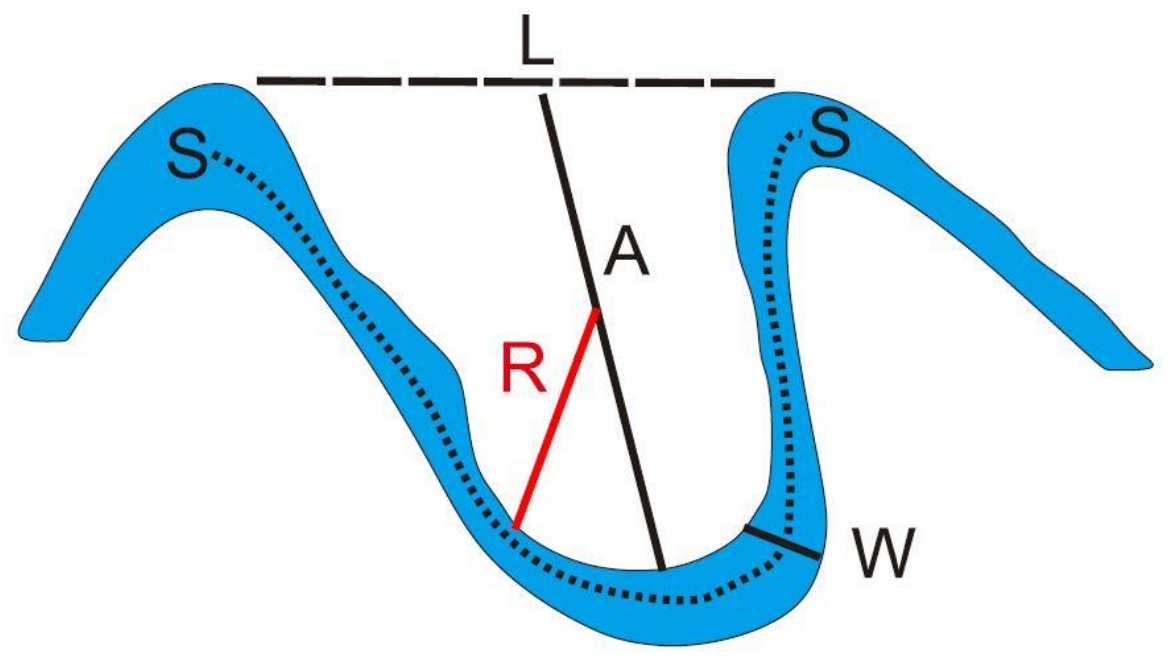

Figure 3. Model of curve winding morphometric parameters

To consider the meander morphometry parameters, the center lines of the research river channels in 1990 and 2016 were digitized into seven series of loop curves that identified changed based on meander curve changed model [5]. Furthermore, it was measured and calculated for each meander curve using a measuring device in Autocad 2013 (Figure 4). 

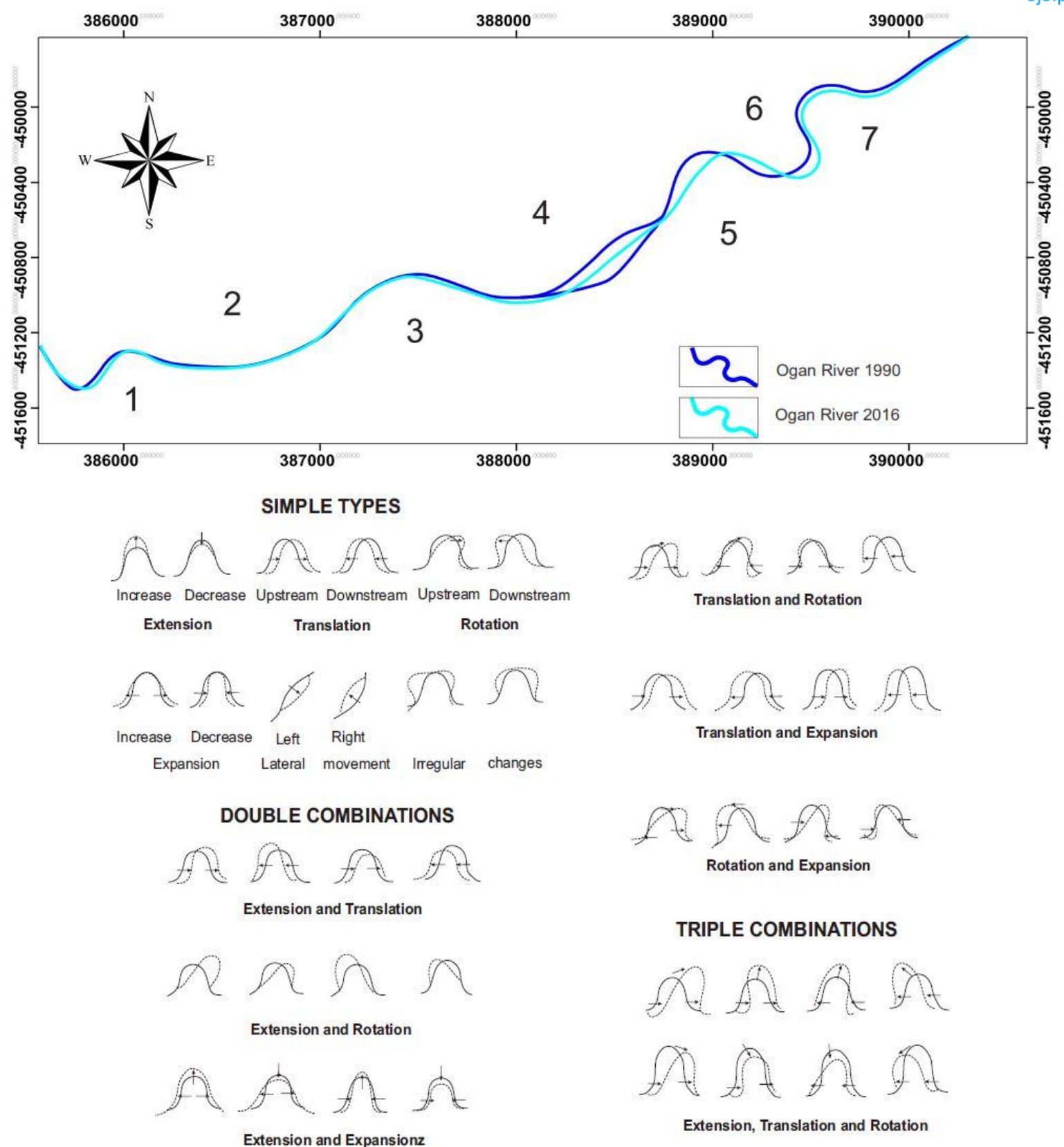

Figure 4 . The center line of the river channel and meander curve change model

\section{Results and Discussion}

\subsection{Land cover change}

Mapping of land cover at the research site had been identified as five classes of land cover consisting of water areas (rivers), mixed plantations, agriculture, shrubs, settlements and open area (attachments). The results of the study on land cover maps have increased the area of land cover for the vegetation area on mixed plantation land and rice fields. Whereas, in bush land, water areas (rivers), settlements areas and open area have decreased (Figure 5). Changes in the use of plantation land experienced a very significant increase in the research location, this was due to the surrounding community who changed the function of the land, especially the bush area as plantation land and rice fields. 


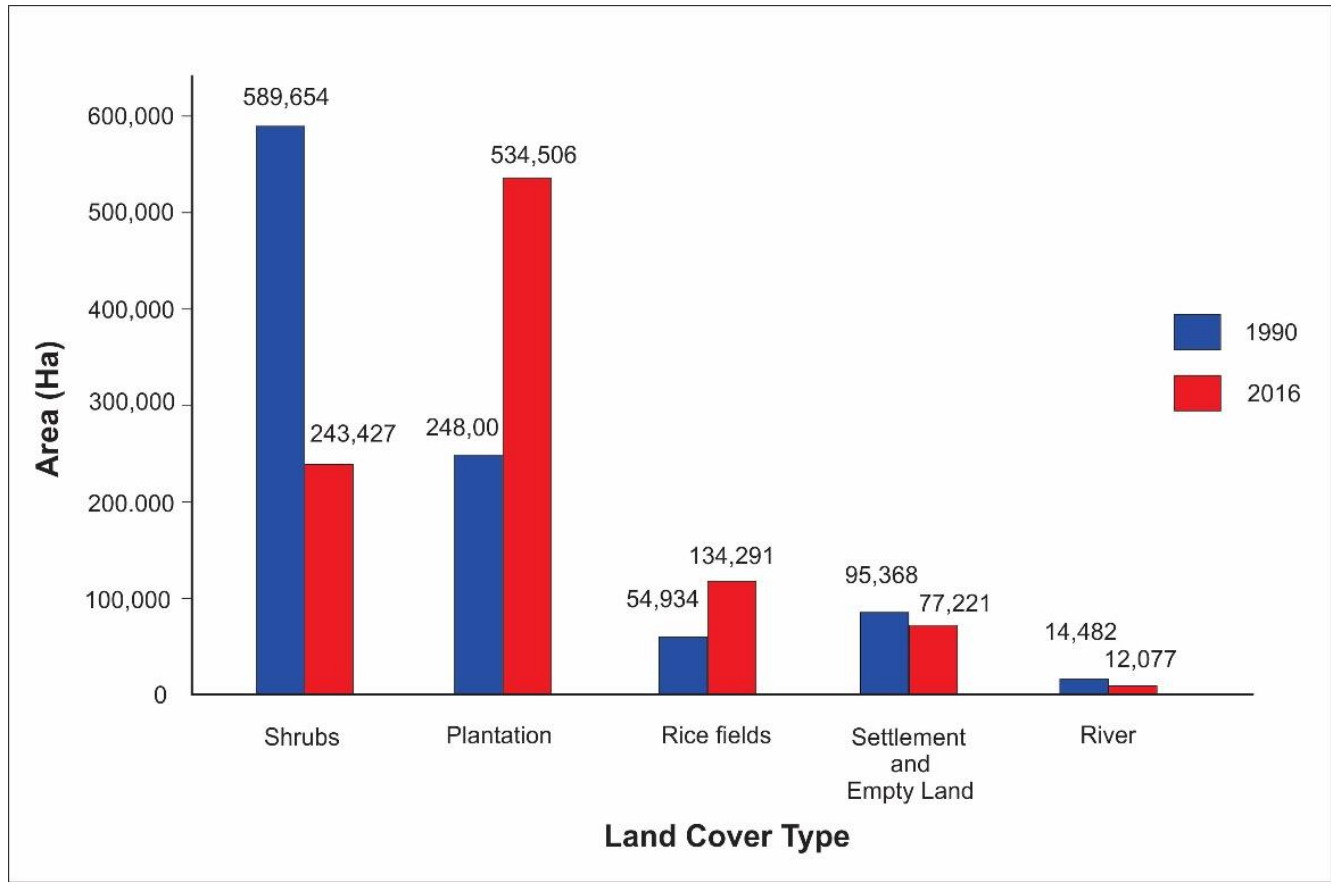

Figure 5. Development of the type of land cover in the research location

\subsection{Changes in Meander Morphometry}

Changes in morphology meander of the seven winding loops in the study show that there are two types of tortuous changes, namely types of simple and combination changes. On the tortuous curves $(5,6$, and
7) are morphological changes with the type of combination namely extension and translation and extension and expansion in river flow in the study location (Figure 6).
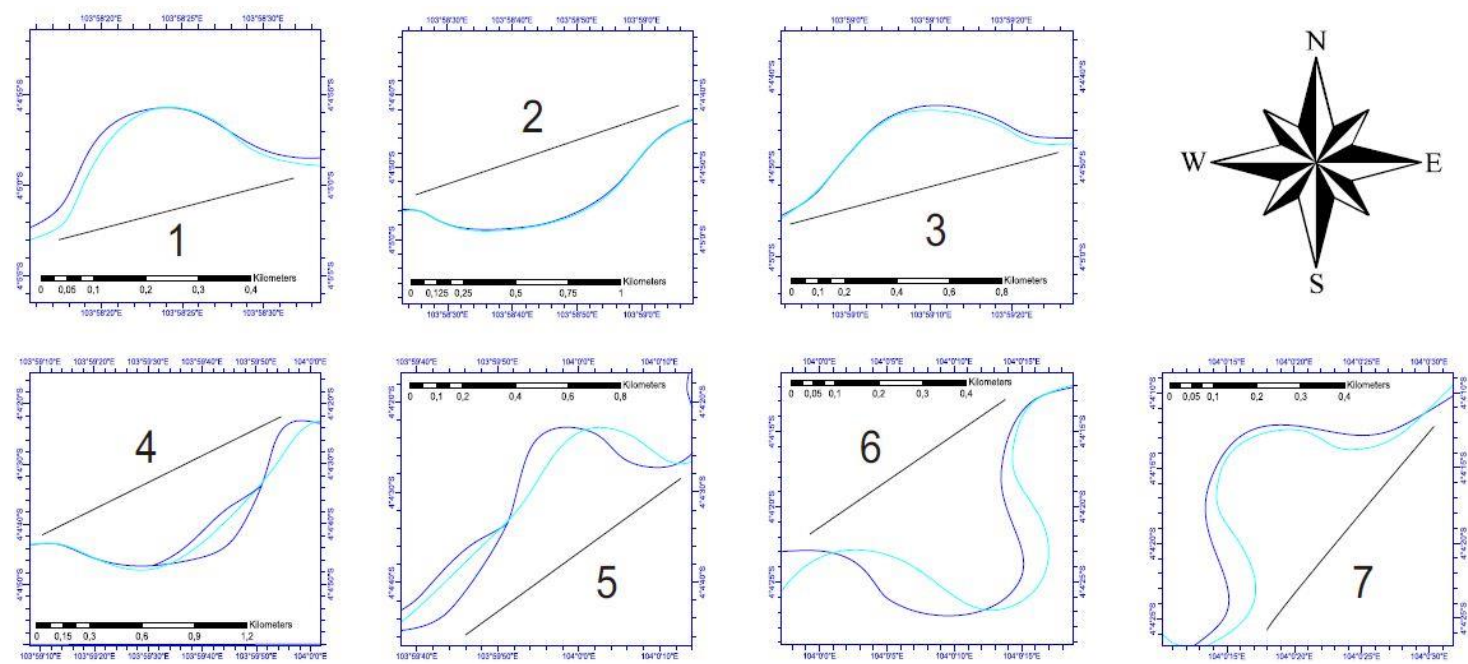

Figure 6. Seven center lines of the river channel at the research location

Based on the calculation results of each entanglement morphometric meander parameter, the average value of $\mathrm{L}$ (meander neck length) and $\mathrm{S}$ (length of water flow), and $\mathrm{R}$ (radius of curvature) have decreased. Conversely, W (river width), A (axis length) and C (sinuosity) have increased. For standard deviation (SD) meander neck length (L), axis length (A), radius of curvature (R), river width (W) and increase in sinuosity (C). Meanwhile, the length of water flow (S) in 1990 was higher than in 2016, which means a decrease (Table 1). 
Table 1. Results of calculation of meander morphometric parameters

\begin{tabular}{|c|c|c|c|c|c|c|c|c|c|c|c|c|c|c|}
\hline \multirow{2}{*}{ Number } & \multicolumn{6}{|c|}{1990} & \multicolumn{6}{|c|}{2016} & \multicolumn{2}{|c|}{ Morphological change (1990-2016) } \\
\hline & $L(m)$ & $S(m)$ & $W(m)$ & $A(m)$ & $R(m)$ & C & $\mathrm{L}(\mathrm{m})$ & $S(m)$ & $W(m)$ & $A(m)$ & $R(m)$ & C & Type of change & Description \\
\hline 1 & 548 & 732 & 25 & 161,6 & 69,4 & 1,336 & 449,4 & 728 & 40,6 & 165,4 & 66 & 1,62 & \multirow{7}{*}{$\begin{array}{l}\text { Simple } \\
\text { Simple } \\
\text { Simple } \\
\text { Cutoff } \\
\text { Double } \\
\text { Double } \\
\text { Double }\end{array}$} & \multirow{7}{*}{$\begin{array}{c}\text { Expansion } \\
\text { Extension } \\
\text { Translation } \\
\text { Cutoff } \\
\text { Extension and Translation } \\
\text { Extension and Translation } \\
\text { Extension and Expansion }\end{array}$} \\
\hline 2 & 1422 & 1577 & 40 & 220,14 & 141,6 & 1,109 & 1354 & 1582 & 39 & 231,6 & 143,4 & 1,168 & & \\
\hline 3 & 1452 & 1768 & 30 & 286,6 & 139,2 & 1,218 & 1424 & 1789 & 35,2 & 297,6 & 141,8 & 1,256 & & \\
\hline 4 & 1470 & 2178 & 32 & 256,8 & 234,6 & 1,482 & 1614 & 2044 & 47,2 & 377,6 & 250,8 & 1,266 & & \\
\hline 5 & 912 & 1846 & 58 & 292,2 & 127 & 2,024 & 1132 & 1702 & 79,4 & 307,8 & 127 & 1,504 & & \\
\hline 6 & 1163 & 1149 & 71 & 239 & 152,8 & 0,988 & 461,6 & 1237 & 79,4 & 240 & 140,2 & 2,68 & & \\
\hline 7 & 369 & 1021 & 44 & 170,6 & 117,4 & 2,767 & 372,2 & 1101 & 51,2 & 162,6 & 124 & 2,958 & & \\
\hline Mean & 1048 & 1467 & 42,86 & 232,42 & 140,3 & 1,56 & 972,5 & 1455 & 53,14 & 254,7 & 141,9 & 1,779 & & \\
\hline Min & 369 & 732 & 25 & 161,6 & 69,4 & 0,988 & 372,2 & 728 & 35,2 & 162,6 & 66 & 1,168 & & \\
\hline Max & 1470 & 2178 & 71 & 292,2 & 234,6 & 2,767 & 1614 & 2044 & 79,4 & 377,6 & 250,8 & 2,958 & & \\
\hline SD & 418,15 & 476,9 & 15,27 & 48,01 & 45,95 & 0,583 & 490,1 & 420,4 & 17,31 & 72,67 & 50,94 & 0,677 & & \\
\hline
\end{tabular}

Based on the calculation above, the sinuosity index values on the meander 1, 6 and 7 curves have been obtained representing changes that increase with the sinuosity values of $1.62,2.68$ and 2.958 respectively. This, it can be said that the meander is growing or increasingly meander according to [6]. That rivers have meander evolution types obtained through the sinuosity index value. The sinuosity index value with a ratio $<1.1$ is a straight groove, a sinuosity index with a ratio of $1.1-1.5$ is a sinuous, and the sinuosity index ratio $>1.5$ is a meander (Figure 7 ).

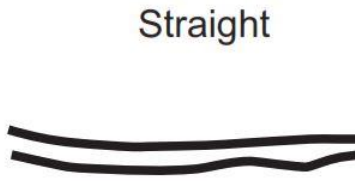

$\mathrm{SR}<1.1$
Sinous

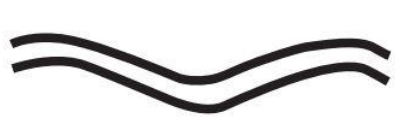

SR 1.1 to 1.5
Meander

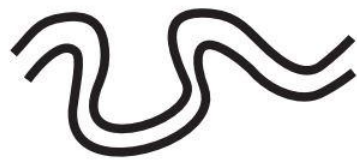

$\mathrm{SR}>1.5$

Figure 7. Evolution type meander based on sinuosity index value

\subsection{Paired T-test analysis}

Analysis of the statistical tests of two paired samples was carried out on the same two meander morphometric parameter data in 1990 and 2016 using Microsoft Excel. Based on this paired T-test there is a significant change in the width of the river (W) with a confidence degree of 95\%, while for the length between the neck meander (L), radius of curvature (R), water flow length (S), axis length A) and sinuosity (C) there were no significant differences (Table 2).

Table 2. Paired T-test results

\begin{tabular}{|c|c|c|c|c|c|}
\hline $\begin{array}{c}\text { Meander } \\
\text { Parameter }\end{array}$ & $\begin{array}{c}\text { Average } \\
\text { difference } \\
\text { between variables }\end{array}$ & $\begin{array}{c}\text { Standart } \\
\text { deviation }\end{array}$ & T-Tab & $\begin{array}{c}\text { Degree of } \\
\text { freedom }\end{array}$ & T-Count \\
\hline W & 1,86 & 30,82 & 2,45 & 6 & $-3,60$ \\
\hline R & 1,60 & 8,84 & 2,45 & 6 & $-0,48$ \\
\hline A & $-22,24$ & 44,17 & 2,45 & 6 & $-1,33$ \\
\hline L & 75,54 & 298,97 & 2,45 & 6 & 0,67 \\
\hline S & 12,57 & 93,28 & 2,45 & 6 & 0,36 \\
\hline C & $-0,22$ & 0,70 & 2,45 & 6 & $-0,82$ \\
\hline
\end{tabular}

\subsection{Pearson Correlation Test}

The Pearson correlation test was performed on both tortuous parameters in 1990 and 2016 using the SPSS 14 program. Based on the Pearson correlation test there is a significant relationship between radius of curvature (R) and water flow length $(\mathrm{S})$, axis length
(A) and meander neck length (L) and water flow length (S) with a confidence level of $95 \%$. A significant relationship also lies in the river width $(\mathrm{W})$ with the radius of curvature $(\mathrm{R})$ and between the water flow length (S) and the axis length (A), which is obtained with a confidence level of $99 \%$. Whereas, between 
sinuosity $(\mathrm{C})$, river width $(\mathrm{W})$, curvature radius $(\mathrm{R})$, meander neck length (L), water flow length (S) and axis length (A) there is no significant relationship (Table 3).

Table 3. Pearson correlation test

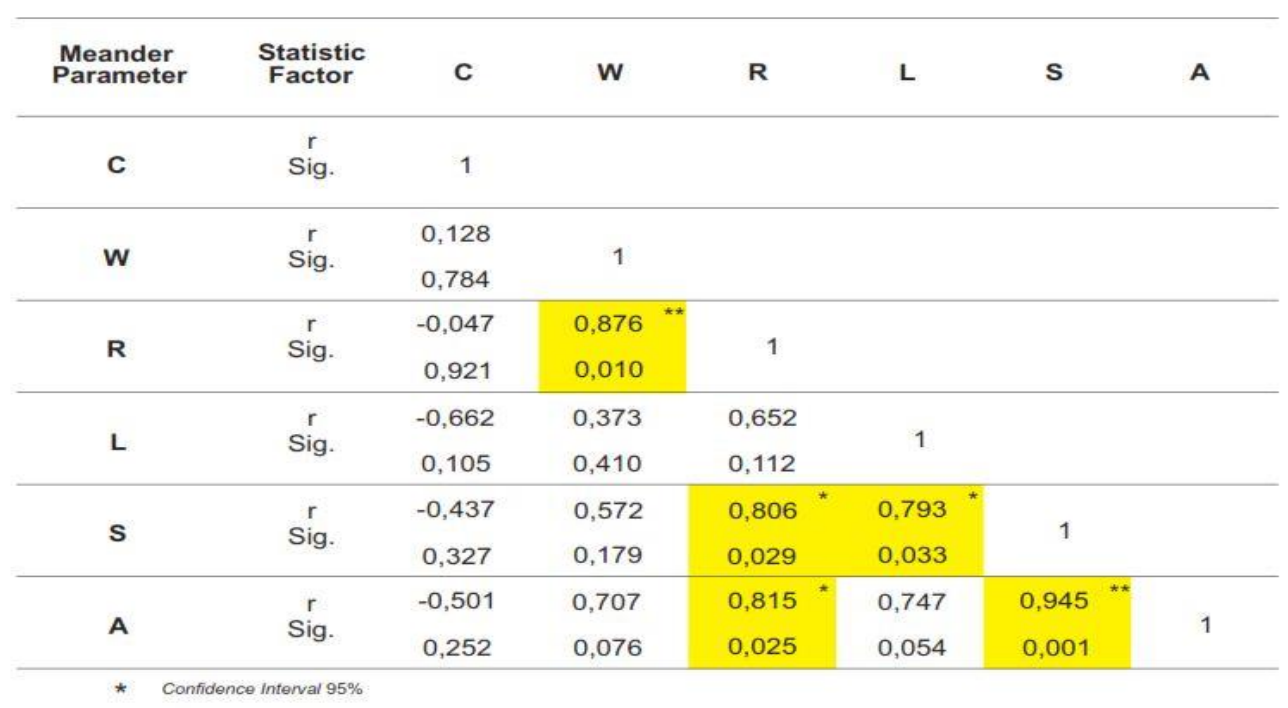

** Confidence Interval $99 \%$

\section{Conclusion}

Indirectly there has been degradation in the flow of morphology, especially in river meander. on the land cover map there has been a very significant change in bush land into plantation land. This affects the characteristics of winding morphometric parameters with increasing river width parameters and sinuosity ratio based on calculation results. an increase in river width can cause erosion on the banks of the river. maintain bush natural vegetation from river systems without changing the function of land around the banks of the river, so as to control erosion and evaluate the risk of flooding.

\section{Acknowledgement}

The author would like to thank Allah S.W.T. who have given lifelong blessings to date, so that the author can complete the research and creation of this journal. As well as the Parents who have ceaselessly provided support in the form of prayer and material.

\section{References}

[1] Hooke, J. M., 2013. "River Meandering," in Treatise on Geomorphology., vol. 9. Shroder J. F, Ed. Academic Press San Diego, 2013, pp. 260-288.

[2] As-syakur A.R, Suarna I.W, Adnyana I.W.S, Rusna I.W, Laksmiwati I.A.A, Diara I.W. (2008). "Studi Perubahan Penggunaan Lahan di DAS Bandung". Jurnal Bumi Lestari, pp. 100-108.

[3] Jia K, Xiangqin W, Xingfa G, Yunjun Y, Xianhong $\mathrm{X}$, Bin L. 1014. Land cover classification using Landsat 8 Operational Land Imager data in Beijing, China. Geocarto International. 19: 941-951.

[4] Yousefi, S., Poughasemi, H.R, Hooke, J., Navartil, O., Kidova, A., 2016. Changes in morphometric meander parameters identified on the Karoon River, Iran, using remote sensing data. Geomorphology. GEOMOR 5707.

[5] Hooke, J., 1984. Changes in river meanders - a review of techniques and results of analyses. Progress in Physica Geography 8, 473-508

[6] Charlton, R. 2008. Fundamentals of Fluvial Geomorphology. London and New York: Rouledge Taylor and Francis Group. 